\title{
The Effectiveness of Online-Based Licensing Services at The Capital Investment and Integrated One-Stop Services (DPM-PTSP) in The Fourth Industrial Revolution
}

\author{
Asna Aneta, Erni Soleman, Sukarman Kamuli \\ Public Administration, Faculty of Economics, State University of Gorontalo \\ Email: asnaatiek.aneta@ung.ac.id
}

(Received: December 12-2019; revised: February 15-2020; published: June 31-2020)

\begin{abstract}
The research aims to analyze the effectiveness of online-based licensing services at the Capital Investment and Integrated One-stop Services (DPM-PTSP) in the Fourth Industrial Revolution. The research method was using a survey method with an explanatory approach and serving the research findings in a descriptive-quantitative way. The informants were the state civil apparatuses at DPM-PTSP. The data collection techniques were: 1) Observation, 2) Interview, and 3) Questionnaire. Meanwhile, the data analysis techniques used were data reduction, data display, and data verification interpreted quantitatively and qualitatively and taken from primary and secondary data. The research findings were: 1) The integrated one-stop service concept to improve the quality of licensing services in Gorontalo in the Fourth Industrial Revolution; 2) The determinants of the quality of licensing services in Gorontalo in the Fourth Industrial Revolution; 3) The effectiveness of online-based licensing services at DPM-PTSP in terms of a) Services: less optimized online-based licensing service implementation. The evidence argued that the service was ineffective in terms of human resources which were low. Either the staff or facilities and infrastructures were inadequate, b) Online-based program implementation: the implementation of online-based licensing services was not optimized as it was a new program at DPM-PTSP. Besides, several challenges started to appear; such as the limited number of staff who provided the online-based service for the community, the community's inadequate understanding of how to use the Internet and the online-based licensing services, lack of facilities and infrastructures, and others. The challenges could be reduced by optimizing the education and training for the staff, optimizing socialization from DPM-PTSP to the community who were not experienced in using technology networks, providing facilities and infrastructures needed by providing budget, and optimizing service provision. Furthermore, DPM-PTSP should well respond to the customers' complaints and improve their service performances.
\end{abstract}

Keywords: Effectiveness of Licensing Services; Online-based; the Fourth Industrial Revolution

\section{INTRODUCTION}

Local autonomy encourages each region to implement its autonomy with an effective democracy which is expected to run democratically (H. M. S. Saggaf, 2016; Wenda \& Akib, 2015). With local autonomy, each region should manage and use all kinds of resources; such as economic, natural, and human resources locally available to sustain their local development 
144 Jurnal Ilmiah Ilmu Administrasi Publik: Jurnal Pemikiran dan Penelitian Administrasi Publik Volume 1o Number 1, January - June 2020. Page 143-158

(Aneta et al., 2019; Ansell \& Gash, 2008; Lamangida et al., 2017; Van Meter \& Van Horn, 1975).

The local autonomy will be consistently developed to achieve an independent local autonomy. As a result, the region will gain more independencies. Besides, with local autonomy, people can actively give responses to their needs, capacities, and aspirations. The local autonomy implementation will trigger new thinking of how set an effective and efficient authority. That means democratic governance (Aneta et al., 2019; Saputra et al., 2019). Besides, the current government is not only the responsibility of the government but also all actors in a state. However, the government's role is still important in terms of public service provision. Meanwhile, the fundamental public service consists of three aspects i.e. goods, service, and administrative. The administrative services include both non-licensing and licensing services. Moreover, one of the indicators of effective local autonomy implementation is the ability of the local government to provide public services. Therefore, people should get easy, affordable, quick, and friendly services and thus public satisfaction can be achieved. Services are the manifestation of the government's dedication to the public which continues until the $21^{\text {st }}$ Century in the Fourth Industrial Revolution and is going on.

In the Fourth Industrial Revolution, one of the most effective public services is an online one. An online public service helps people use their time more efficiently. They are not obliged to visit the service directly and spend much time to get licenses.

The Indonesia government has instructed all local heads to implement the integrated onestop licensing service through the Regulation of the Ministry of Home Affairs Number 24 of 2006 on the Guidelines on the Integrated One-Stop Licensing Implementation. In accordance with the Regulation, the local heads should select either agency, office, or board which suits the needs and managing capabilities of their regions to be the institution running the Licensing Service. With the establishment of the integrated one-stop licensing service as an institution providing licensing services, people should only visit one office, board, or agency (Lamangida et al., 2017; Smith \& Akib, 2015).

The implementation of an integrated one-stop service is an activity in which we are implementing both licensing and non-licensing services whose management process begins with the application stage and ended with the document issuance stage conducted in one place. The PTSP head is authorized to sign any licenses process, indicating a simplified service. Service simplification is an effort made to minimize the time, procedures, and costs in licensing and non-licensing services. Licensing means giving legality to an individual or a business actor, either in the form of license or business registration certification. Meanwhile, the integrated one-stop service (PTSP) implementation is expected to cut the time and cost people spend to get licenses (Daraba et al., 2018; Mirdawati et al., 2018; Nasrullah et al., 2018; S. Saggaf et al., 2014; Salam \& Rosdiana, 2015). As a result, the licensing services are more effective, affordable, and easier (Regulation of the Ministry of Home Affairs Number 24 of 2006 on the Guidelines on the Integrated One-stop Licensing Services). Nevertheless, the data show that in Indonesia, several investments are declining. Therefore, some corrective actions in services should be made, one of which is the issuance of the Regulation of the Ministry of Home Affairs Number 24 of 2006 on the Guidelines on the Integrated One-stop Licensing Service (PTSP) Implementation. The regulation demands the local governments to take the following actions: 1) 
Simplification in business licensing systems and procedures, 2) Establishment of local integrated one-stop licensing services, 3) Minimization in the licensing time and cost, 4) Improvement in the licensing systems, 5) Improvement in the information systems, and 6) Monitoring and evaluation of licensing services. All of this information should have been provided online if the government aims to make people get informed.

Meanwhile, one of the best solutions to solve the identified field problem in terms of licensing services in the Fourth Industrial Revolution is that each person gets good, effective, and efficient services. A service is considered effective if able to solve the issue in accessing direct assistance to get a business permit, building permit, and others. Furthermore, a solving service is a quick service which can give solutions in a short time, so people do not have to wait for a long time.

Meanwhile, a service is considered effective if the users (people and others) are having an easy service with brief, quick, and effective, and convenient procedures. The government institution can elevate public service effectiveness by improving working discipline and working ethics. Also, public administration services can be effective if the services can be run in accordance with the civil apparatuses' roles and functions. The roles and functions are important to ease the public and help the government. Moreover, the government is in a vital position to give public services needed by people; such as regulating services or any other services to fill the public needs. Meanwhile, the demand for good and satisfying public services should be met by the government. In terms of services provided by the government or any other organizations, the public is expecting services which suit the era development as well as its social changes and dynamics. Basically, public services engage with a broad aspect of life. Therefore, certain technology is designed to ease and improve the quality of human life. It is information technology or e-Government, the use of information technology by the government to provide information and services for the public. Anggara (2012) argues that e-Government is information technology responding to the government's need for transparency and demand in the more developing era. Also, technology is the response to improve public services which use information and communication technology. Nevertheless, the effectiveness of online-based licensing services is still low, proven by the following indicators: 1. No optimization in the online-based licensing services, minimum socialization of procedures or guidelines on the online-based licensing implementation, and 2. Limited facilities and infrastructures and apparatuses' capabilities.

Based on the research background, the research is focused on the effectiveness of onlinebased licensing services at the Capital Investment and Integrated One-stop Licensing Services (DPM-PTSP) in Gorontalo and aims to the effectiveness of online-based licensing services at the Capital Investment and Integrated One-stop Licensing Services (DPM-PTSP) in the Fourth Industrial Revolution.

\section{METHOD}

The research used a survey method with explanatory research (mix methods) which presented the findings in a descriptive-qualitative way, which was a research method describing the reality going on when the research was conducted by collecting and compiling the data in the form of classification. Furthermore, we used a descriptive method. (Creswell \& Creswell, 
146 Jurnal Ilmiah Ilmu Administrasi Publik: Jurnal Pemikiran dan Penelitian Administrasi Publik Volume 10 Number 1, January - June 2020. Page 143-158

2017; Creswell \& Poth, 2018)explained that a descriptive method "was a systematic description of theories and findings relevant to the researched variable". Furthermore, (Creswell, 2013) mentioned that a quantitative research method was "the focus of concern using various methods. It involves a certain approach to analyze data build a conclusion based on figures which were converted into \%". The research was performed in February-July 2018 at the Capital Investment and Integrated One-stop Services (DPM-TSP) of Gorontalo. Furthermore, in terms of research data source(Suharsimi, 2013) stated that "research data source was the subject where the data could be found". (Sugiyono, 2016) argued that data could be collected through either primary or secondary data sources. Primary data sources were the data sources which directly gave the data to the data collectors; while secondary data sources were the data sources which indirectly gave the data to the data collectors. The media of the second source could be another person or documents. Moreover, the data sources of this research were the licensing service staff who provided services for licensing applicants at the Capital Investment and Integrated One-stop Services (DPM-TSP) of Gorontalo. Here are the details: 1) The primary data sources: a. The head of licensing services, b. The staff delivering licensing services, and c. Eight licensing applicants; 2) The secondary data sources: a. Literatures, b. Research finding documents, and c. Data collected at the Capital Investment and Integrated One-stop Services (DPM-TSP) of Gorontalo. Moreover, the data collection techniques were: 1) Observation, 2) Interview, and 3) Questionnaire. Meanwhile, the data analysis techniques used were data reduction, data display, and data verification. The data interpreted in a quantitative and qualitative way were from both primary and secondary sources (Miles et al., 2014).

\section{RESULT AND DISCUSSION}

\section{Research Findings}

\section{The Concept of Integrated One-stop Services to Improve the Licensing Service Quality in Gorontalo}

Based on the result of the interview collaborated with the result of observation, here are the findings of research on the concept of integrated one-stop services to improve the public service quality in Gorontalo.

Table 1 inclines the situations of integrated services at DPM-PTSP of Gorontalo. Optimal services were indicated by the staff's responsiveness to the licensing services expected by public. In other words, the integrated one-stop services in Gorontalo had been in accordance with SOPs while improving the public service quality. All licensing businesses were completed on time or even prior to the deadline. It is in line with (Junus \& Napir, 2019) that the optimization of integrated services at DPM-PTSP of Gorontalo was presented by its staff's responsiveness to the licensing management which was run in accordance with the regulations and procedures recommended.

Overall, the integrated one-stop services in Gorontalo had improved the public service quality in Gorontalo well, yet there were still other improvements to make; such as in increasing customer's compliance with licensing application procedures and in the sanction which should be tighter, giving a deterrent effect to the disobedient customers. Meanwhile, the strategies 
which can be implemented by the integrated one-stop services to improve the public service quality in Gorontalo are stable and diversification strategies. The first strategy is best implemented when the fourth aspects impacts customers' compliance with compulsory licensing service fee payment. Moreover, the second strategy should be implemented when the fourth aspects have not been optimized.

Table 1

The Findings of Research on the Concept of Integrated One-stop Services to Improve the Online-based Licensing Service Quality in the Fourth Industrial Revolution in Gorontalo

\begin{tabular}{|c|c|c|c|c|c|}
\hline \multirow{3}{*}{ No. } & \multirow{3}{*}{$\begin{array}{l}\text { Aspects } \\
\text { Evaluated }\end{array}$} & \multicolumn{4}{|c|}{ Research Findings } \\
\hline & & \multicolumn{2}{|c|}{ Plus } & \multicolumn{2}{|c|}{ Minus } \\
\hline & & Findings & Impacts & Findings & Impacts \\
\hline \multirow{2}{*}{1} & \multirow{2}{*}{$\begin{array}{l}\text { Tangibility } \\
\text { (physical form) }\end{array}$} & $\begin{array}{l}\text { Adequate waiting } \\
\text { rooms }\end{array}$ & $\begin{array}{l}\text { Customers' } \\
\text { convenience }\end{array}$ & \multirow{2}{*}{$\begin{array}{l}\text { Less } \\
\text { functioned } \\
\text { queue } \\
\text { facilities }\end{array}$} & \multirow{2}{*}{$\begin{array}{l}\text { Unorganized } \\
\text { queue }\end{array}$} \\
\hline & & $\begin{array}{l}\text { Good computer } \\
\text { facilities }\end{array}$ & $\begin{array}{l}\text { Quicker } \\
\text { services }\end{array}$ & & \\
\hline \multirow[t]{2}{*}{2} & \multirow[t]{2}{*}{ Reliability } & \multirow{2}{*}{$\begin{array}{l}\text { The services } \\
\text { provided suiting } \\
\text { what people needed }\end{array}$} & \multirow{2}{*}{$\begin{array}{l}\text { Optimized } \\
\text { visions and } \\
\text { missions of } \\
\text { the } \\
\text { institution }\end{array}$} & $\begin{array}{l}\text { Unorganized } \\
\text { service } \\
\text { procedures }\end{array}$ & $\begin{array}{l}\text { Lack of } \\
\text { customers' } \\
\text { compliance }\end{array}$ \\
\hline & & & & $\begin{array}{l}\text { Delayed } \\
\text { services }\end{array}$ & $\begin{array}{l}\text { Public } \\
\text { dissatisfaction }\end{array}$ \\
\hline 3 & Responsiveness & $\begin{array}{l}\text { Good } \\
\text { responsiveness }\end{array}$ & $\begin{array}{l}\text { Public } \\
\text { satisfaction }\end{array}$ & & \\
\hline 4 & Assurance & $\begin{array}{l}\text { Assured service } \\
\text { security }\end{array}$ & $\begin{array}{l}\text { Public } \\
\text { satisfaction }\end{array}$ & & \\
\hline 5 & Empathy & $\begin{array}{l}\text { Good empathy } \\
\text { showed by the staff }\end{array}$ & $\begin{array}{l}\text { Customers' } \\
\text { loyalty }\end{array}$ & & \\
\hline
\end{tabular}

Source: Processed data, 2018

The findings will be more optimized if added with the indicators of online-based services and legal and regulation enforcement to encourage customers' compliance.

Integrated services are a set of activities to give protection to the witness against a trade crime conducted by an institution. Public services firstly appeared due to an obligation to implement the government activities, either individual or group ones. The services should be given equally, hence eliminating any discrimination. Besides, the service management should be improved in terms of its procedural transparency and easiness, affordable tariff setting, apparatuses' professionalism while serving, availability of media for the public complaints, and the availability of system monitoring the procedure implementation.

One of the integrated services at DPM-PTSP was licensing services. Licensing services largely contributes to the local own-source revenue. The higher the local own-source revenue, the higher the local autonomy of the region. We need to study the internal control of licensing service fees to achieve an effective and efficient improvement of the implementation of the local own-source revenue from licensing services. Meanwhile, the clear difference between local 
148 Jurnal Ilmiah Ilmu Administrasi Publik: Jurnal Pemikiran dan Penelitian Administrasi Publik Volume 10 Number 1, January - June 2020. Page 143-158

tax/retribution and local retribution lays in the counter-achievement given by the local government. In the local tax/retribution, the counter-achievement is not directly given. On the contrary, in the local retribution, the counter-achievement is directly given to customers who are paying the retribution.

The findings proved that the integrated one-stop services which improved the public service quality in Gorontalo had been by SOPs. All licensing businesses were finished on time, even before the working hours mentioned in SOPs. Moreover, the government's role in the service provision was as the catalyst which accelerated the process. As a result, government organizations would refer to the government itself while providing the best services to the public. Finally, the services would be affordable, quick, and efficient in terms of time and cost.

As a state device, the government should implement good public services. The government, well-known as bureaucracy (including the local government) had been negatively evaluated by the public. In their evaluation, the public perceived that the bureaucratic services were difficult to get, complicated in terms of their requirements, and inflexible in their regulations. These service conditions did not benefit the people. Their bargain position was weak as they only received service products from the government without being able to directly contribute to the products. The government should remember that bureaucracy was established to not only serve their needs but also to the public needs and to create public welfare. Also, the government should face the globalization which gives both challenges and opportunities. The government should be aware of some improvements needed in their public administrative processes, especially in licensing services, to fulfill what public needs quickly and efficiently.

In terms of integrated one-stop services, the services were established to realize a good service management process in either licensing or non-licensing services. Then, the district, city, and provincial governments implemented the services in the form of working units whose main tasks and functions were to provide licensing services. The working units were Technical Services Unit (UPT), Integrated Services Office (KPT), and Unified Licensing Service Agency (BPPT). The establishment aimed to give service easiness in both licensing and non-licensing services in an easy, affordable, quick, and transparent way through one-stop service facilities. It is in line with (Lesmana, 2016). Moreover, the service mechanism included Business License (SIUP) from the Integrated One-stop Licensing Services Board (BPPTSP).

Meanwhile, public services were closely related to the government as one of its responsibilities. The quality of public services directly received by the public was the standard to evaluate the quality of the government. Public services played a crucial role. Because not all services were provided by private institutions, the government should fulfill the public needs which were not provided by the institutions.

Improving licensing services requires a strategy. However, we found that licensing services had a more complex bureaucracy since it dealt with whether the building structure was appropriate. Licensing service documents had a legal force and gave a legal protection people might face in the future. Therefore, the document should be carefully processed. Besides, licensing services required government intervention as the services had both complex administrative requirements and procedural mechanisms.

Overall, the integrated one-stop services had improved the public service quality in Gorontalo, but several other improvements; such as improving services which had not been 
optimized and increasing customer's compliance with licensing application procedures and in the sanction which should be tighter, giving a deterrent effect to the disobedient customers; were needed to make. Meanwhile, the strategies which can be implemented by the integrated one-stop services to improve the public service quality in Gorontalo are stable and diversification strategies. The first strategy is best implemented when the four aspects impact customers' compliance with compulsory licensing service fee payment. Moreover, the second strategy should be implemented when the four aspects have not been optimized. Also, the services should be more improved to make the public comply with their duties. (Katavich, 2013) argues that quality and public satisfaction are closely connected. Quality encourages the public to build a strong relationship with an organization. After a while, the relationship enables the organization to understand what the public expects and needs. The result is, the organization can improve public satisfaction by optimizing the public pleasant experiences and minimize the less pleasant ones. Later, the satisfaction may trigger the public loyalty to the organization which has provided satisfying quality.

Similarly, (Kaleem et al., 2013) believe that optimal performances shown by the staff will positively impact public perception. The evaluation of apparatuses' performances is the evaluation used by the management to give information to the apparatuses about their performance quality based on the perspective of corporate interests individually. The evaluation is crucial because staff can affect the perception of customers. In other words, the staff is a part of the service so they are functioned as both communicators and image representation of an organization.

Moreover, sanction was an important aspect to motivate the effectiveness of integrated one-stop services to improve public service quality in Gorontalo. It is in line with (Harmelia \& Endriani, 2019) that retribution/tax sanction consists of administrative sanction and criminal sanction. The administrative sanction is imposed when someone has violated the regulation, especially of duties mentioned in UU KUP. The sanction can be in the form of interests, fine, or cost increases which must be paid. Meanwhile, the criminal sanction can be in the form of imprisonment. It is in line with (Sumada, 2018). In her research on the evaluation of integrated one-stop licensing primary excellent services in BPPT of Kota, she concluded that the excellent service processes had not been optimal. Furthermore, some improvements should be made, particularly in administrative services to track people's data which had to be stored.

According to the law of tax/retribution, there are two types of sanction i.e. criminal and administrative sanctions. The sanction is imposed on those who do not pay their tax/retribution. A higher sanction will certainly affect customers' compliance with retribution/tax payment. It is in line with (Bratamanggala, 2017) that retribution/tax sanctions positively affect customers' compliance with retribution/tax payment.

Meanwhile, the aspects considered good yet requiring some improvements were monitoring and some technical stuff in licensing services. Toding (2016:386) clarifies that one of the functions of human resources management is monitoring. Monitoring means observing the whole organizational activities to ensure that all activities being run have been in line with the plan. With monitoring, the staff will be motivated and thus can finish their duties well. Besides, with monitoring, errors and mistakes can be minimized. It is in line with Djafri (2018) that excellent service management should improve its monitoring of the services, especially administrative services and technical implementation. 
150 |Jurnal Ilmiah Ilmu Administrasi Publik: Jurnal Pemikiran dan Penelitian Administrasi Publik Volume 1o Number 1, January - June 2020. Page 143-158

Monitoring is an activity which compares or measures what is or has been conducted using standard criteria or based on the plan (Handoko, in Ardansyah \& Wasilawati, 2014:154). Monitoring should be thoroughly conducted to get information about task implementation in every organizational unit environment, deviation if any, and efforts made to achieve the goals. If there is any deviation, the manager can immediately take corrective actions.

\section{The Determinants of Licensing Service Quality in Gorontalo}

Based on the result of the interview, Table 4.2 presents the determinants of licensing service quality in Gorontalo.

Table 2

The Determinants of Licensing Quality in Gorontalo

\begin{tabular}{|c|c|c|c|c|c|}
\hline \multirow{3}{*}{ No. } & \multirow{3}{*}{$\begin{array}{c}\text { Aspects } \\
\text { Evaluated }\end{array}$} & \multicolumn{4}{|c|}{ Research Findings } \\
\hline & & \multicolumn{2}{|c|}{ Plus } & \multicolumn{2}{|c|}{ Minus } \\
\hline & & Findings & Impacts & Findings & Impacts \\
\hline \multirow{2}{*}{1} & \multirow{2}{*}{$\begin{array}{l}\text { Organization } \\
\text { (communication } \\
\text { and coordination) }\end{array}$} & \multirow{2}{*}{$\begin{array}{l}\text { Coordination } \\
\text { with relevant } \\
\text { offices }\end{array}$} & \multirow{2}{*}{$\begin{array}{l}\text { Easier } \\
\text { management }\end{array}$} & Less socialization & $\begin{array}{l}\text { Confusion among } \\
\text { people/customers }\end{array}$ \\
\hline & & & & $\begin{array}{l}\text { Technical stuff's } \\
\text { low performances }\end{array}$ & $\begin{array}{l}\text { Longer reviewing } \\
\text { time }\end{array}$ \\
\hline \multirow{2}{*}{2} & \multirow{2}{*}{$\begin{array}{l}\text { Leadership } \\
\text { (monitoring) }\end{array}$} & \multirow{2}{*}{$\begin{array}{l}\text { Optimal } \\
\text { services given } \\
\text { by the staff }\end{array}$} & \multirow{2}{*}{ Better services } & $\begin{array}{l}\text { Low leadership and } \\
\text { monitoring levels }\end{array}$ & $\begin{array}{l}\text { Low working } \\
\text { outcomes }\end{array}$ \\
\hline & & & & $\begin{array}{l}\text { Damaged facilities } \\
\text { and infrastructures }\end{array}$ & $\begin{array}{l}\text { Low working } \\
\text { outcomes }\end{array}$ \\
\hline 3 & $\begin{array}{l}\text { Apparatuses' } \\
\text { commitment }\end{array}$ & $\begin{array}{l}\text { Staff's loyalty } \\
\text { while serving }\end{array}$ & $\begin{array}{l}\text { Expected } \\
\text { licensing } \\
\text { services }\end{array}$ & & \\
\hline 4 & $\begin{array}{l}\text { Competences and } \\
\text { skills }\end{array}$ & $\begin{array}{l}\text { Good } \\
\text { supports from } \\
\text { the manager }\end{array}$ & $\begin{array}{l}\text { Better } \\
\text { performances }\end{array}$ & & \\
\hline 5 & $\begin{array}{l}\text { Compliance with } \\
\text { SOPs }\end{array}$ & $\begin{array}{l}\text { SOP and } \\
\text { SPM } \\
\text { availability }\end{array}$ & $\begin{array}{l}\text { The availability } \\
\text { of guidelines on } \\
\text { licensing } \\
\text { service } \\
\text { retribution }\end{array}$ & $\begin{array}{l}\text { Confusion over the } \\
\text { SOPs }\end{array}$ & $\begin{array}{l}\text { Many violations of } \\
\text { SOPs }\end{array}$ \\
\hline
\end{tabular}

Referring to the result of the interview collaborated with the result of observation; lack of online-based licensing socialization was due to the limited number of staff as human resources. Consequently, information about the licensing services, including the retribution payment, was little. In terms of human resources and facilities and infrastructures, we found that the facilities and infrastructures were inadequate, especially in technical services. As a result, while serving, 
the staff had to wait for the facilities and infrastructures which were not in use. Sometimes, they were not in good condition.

Furthermore, the number of technical staff should be added because they had to not only manage the field works but also directs and provide recommendations for those who would have building projects.

Besides, the manager's attitude was one of the crucial aspects. Along with his supports and commitment, the staff would provide services well. Meanwhile, we also found that the manager had shown good attitudes but his commitment should be improved. Furthermore, the administrative staff should also improve their empathy while serving.

Since the issuance of licensing services concerns the safety of residents which will occupy a building, direct inspection is necessary to ensure the building structure has met the standards and is properly located. Licensing services require more specific support facilities than other licensing services. Because of the complexity of issuing permit documents both in administrative services and field inspection, there is also a need for human resources with specific knowledge about buildings.

Public service quality is one of the vital components in the implementation of public services by government institutions, state-own enterprises, or private corporates. Here, as one of the public service providers, the local government also contributes to creating excellent services improving public satisfaction. One of the public licensing services provided by the government is licensing services. The licensing service quality is the determinant which draws investors' interests in making investments in a certain region. Furthermore, the need for quality is mentioned in the local regulation which supports and legitimizes any local licensing institutions to provide excellent services that can create a healthy climate condition for the local economic development.

Also, we figure out the determinants of public service quality in Gorontalo which were communication, resources, and disposition or attitude of managers and bureaucratic structure. In terms of communication, socialization was still very rarely made or made in the village level only. Besides, the resources were low in terms of quality and quantity of staff and infrastructures. Contrastively, we found that the manager's attitude was good and committed, so was the bureaucratic structure. Meanwhile, the most dominant determinant was the quantity of staff and infrastructures.

In terms of communication, socialization was still very rarely made or made at the village level only. We have to remember that socialization is a crucial determinant since many people were not aware of their responsibility to pay retribution. (Warouw et al., 2018) confirm that tax socialization is expected to be able to improve public compliance with tax payment so the amount of tax received can meet the target. The improvement of compliance is proven by the increased number of people who pay their taxes and report and deliver SPT and the decreased number of people with arrears and sanctions, either administrative or criminal ones.

The resources intended were the facilities and infrastructures in the field and in administrative services. We found that the facilities and infrastructures, especially in technical services, were inadequate. Consequently, when performing technical services, the staff had to wait for the facilities and infrastructures which were not in use. Sometimes, they were not in good condition. Besides, the number of the technical staff was so small. 


\author{
152 Jurnal Ilmiah Ilmu Administrasi Publik: Jurnal Pemikiran dan Penelitian Administrasi Publik \\ Volume 1o Number 1, January - June 2020. Page 143-158
}

The manager's attitude was one of the crucial aspects as his supports and high commitment would encourage the staff to serve well. In terms of the manager's attitude, we found that the manager had shown a good attitude despite his commitment which should be improved, especially the technical manager's attitude and administrative staff who should increase their empathy while serving.

Since the issuance of licensing services concerns the safety of residents which will occupy a building, direct inspection is necessary to ensure the building structure has met the standards and is properly located. Licensing services require more specific support facilities than other licensing services. Because of the complexity of issuing permit documents both in administrative services and field inspection, there is also a need for human resources with specific knowledge about buildings.

Also, we figure out the determinants of public service quality in Gorontalo which were communication, resources, and disposition or attitude of managers and bureaucratic structure. In terms of communication, socialization was still very rarely made or made at the village level only. Besides, the resources were low in terms of quality and quantity of staff and infrastructures. Contrastively, we found that the manager's attitude was good and committed, so was the bureaucratic structure. Meanwhile, the most dominant determinant was the quantity of staff and infrastructures.

Meanwhile, another important internal aspect of governance was the human resource competencies and facilities and infrastructures. (Liu et al., 2019) conveys that one of the factors affecting work achievements is staff competence. In other words, human resources are necessary for an organization. Despite numerous facilities, infrastructures, and human resources, an organization will not be well run without reliable human resources (Aneta et al., 2019; Saputra et al., 2019).

\title{
3. The Effectiveness of Online-based Licensing Services in the Fourth Industrial Revolution
}

Table 3 presents our findings of the effectiveness of online-based licensing services in the Fourth Industrial Revolution. The indicators used were: 1) Service procedures, 2) Time of service completion, 3) Service cost, 4) Service products, 5) Service facilities and infrastructures, 6) Staff's competences, and 7) Staff's IT competences.

This research was focused on the effectiveness of online-based licensing services with the indicators i.e. 1) Service procedures with the score percentage of $80.53 \%$ indicated weaknesses of $19.47 \%$. Therefore, these several aspects should be optimized: a) The use of information: the procedures or guidelines on the implementation of an online system documented or broadcasted using a language or information understood by the service users. Printed media, RRI, TVRI, and online media were examples of the system, b. Information accuracy: easy and transparent service procedures; 2) Time of service completion: a) Time transparency (the transparency of the time of service completion), b) Effective time achievement, from the application to the certificate issuance; 3) Cost service transparency: a) tariff breakdown, b) no retribution besides from the government instruction; 4) Service product satisfaction: a) Service quality: the service implementation should be well run and follow the procedures, making consumers satisfied, b) Service quantity: all the processes should be 
following the procedures, c) Products provided should be accurate, correct, and valid; 5) The improvement of service facilities and infrastructures had the highest score percentage of $84.21 \%$, indicating that the office had been equipped with facilities that supported their staff's performance and services. The weaknesses, with the percentage of $13.79 \%$, should be improved. Here are the details of the weaknesses: a) Due to the adequate Internet facilities, online-based services should be more supported, b) Infrastructures that could support the services; such as the Internet, should be punctual; 6) The staff's competences while serving had the score percentage of $81.01 \%$. Capacity building for the staff, as human resources, should be conducted through training. We found that delayed online-based services were due to a lack of staff operating the Internet instead of a lack of Internet network. In other words, the weaknesses, with the percentage of $18.99 \%$, can be improved through a) Education and training for the staff as the human resources who are responsible for serving and fulfilling their tasks based on their professionalism, b) Solving staff: the staff, as the service providers, should be responsible for the quality of services given and solution for the complaints proposed by the public; 7) IT professionalism: the services should be able to be accessed through digital information. Also, the online services should be socialized and set to assist the public in all situations and conditions, especially in the current Covid-19 pandemic, which forbade the service providers and users to have a face-to-face meeting.

Table 3

The Effectiveness of Online-based Licensing Services at DPM-PTSP of Gorontalo

\begin{tabular}{|c|l|c|c|c|}
\hline No. of Table & \multicolumn{1}{|c|}{ Respondents' Statements } & Score & Percentage (\%) & Category \\
\hline 4.1 & Service procedures & 153 & 80.53 & Good \\
\hline 4.2 & Time of service completion & 155 & 81.58 & Good \\
\hline 4.3 & Service cost & 155 & 81.58 & Good \\
\hline 4.4 & Service products & 157 & 82.53 & Good \\
\cline { 1 - 3 } 4.5 & $\begin{array}{l}\text { Service facilities and } \\
\text { infrastructures }\end{array}$ & 160 & 84.21 & Excellent \\
\hline 4.6 & Staff's competences & 154 & 81.01 & Good \\
\hline 4.7 & Staff's IT competences & 152 & 80.01 & Good \\
\cline { 1 - 2 } Total & 939 & 80.22 & Good \\
\cline { 1 - 3 } Mean & 154 & \multicolumn{2}{|c}{} \\
\cline { 1 - 3 }
\end{tabular}

Source: Processed data, 2018

In terms of the implementation of online-based licensing services in the Fourth Industrial Revolution in the Capital Investment and Integrated One-stop Services of Gorontalo, we found that: 1 . Service procedures: The service procedures or guidelines were unavailable. Furthermore, there was no information board which displayed the online licensing services so the staff had to inform the licensing procedures to the applicants directly. Meanwhile, the service procedures were not easy and understandable. The applicants found it difficult to operate the online licensing program because they were not accustomed to using a computer. Consequently, they had to be assisted by the staff; 2 . Time of service completion: There was time transparency. The applicants had time transparency when applying for licenses. However, 
154 Jurnal Ilmiah Ilmu Administrasi Publik: Jurnal Pemikiran dan Penelitian Administrasi Publik Volume 10 Number 1, January - June 2020. Page 143-158

punctuality should be improved. There was one applicant who declared that his license completion was delayed. Furthermore, there were the staff who were deliberately leaving their duties during the working hours, causing delayed licensing processes; 3. Service cost: There were tariff details and no other retribution besides the tariff determined. Besides, the staff had given information about the service cost to the applicants and the cost had to be paid by the Building Permit applicants only; while the other customers were given no charge/nonretribution. However, the staff still violated the SOPs by conducting certain practices which charged unspecified tariff to the customers. Furthermore, there were other retributions in the floor plan depiction. The applicants requested the floor plan depiction, which was their responsibility, to the staff, making the staff asked for some unspecified retribution; 4 . Service products: The service delivery was good and thus satisfied the customers. In terms of service products with the indicator "quality" (the service delivery should be smoothly run and satisfy customers) and "quantity" (all licensing processes should be in accordance with SOPs), in the implementation of the indicator "quality" (all licensing processes should be smoothly run and in accordance with the SOPs), there were many customers who did not submit the licensing requirements well, delaying the licensing process and thus making them disappointed. Moreover, in terms of "quantity", not all processes had been run in accordance with the procedures.

Responding to the issues, we suggested the following solutions: 1) Building the human resources' capacity: a) Recruiting more staff with IT qualification, b) Giving necessary training to the staff who did not understand the technical operation in online-based licensing. The training could be in the form of technical guidance and education and structuralized training; 2) Optimizing the socialization of licensing service procedures. The procedures should be accessible and displayed on information board, brochures, pamphlets, newspapers, electronic media as RRI, TVRI, and online media; 3) Establishing cooperation with all relevant stakeholders, offices, apparatuses, and all potential customers; and 4) Providing budgets as the capital to deliver licensing services since the most important determinant here was budget.

The solution for the issue in the online licensing certificate issuance in the Fourth Industrial Revolution depends on how DPM-PTSP responds to the Industrial Revolution. Both the director and staff should be responsive to survive in the globalization era and solve the problems. The globalization era and the $21^{\text {st }}$ Century development should be well responded to, especially during the Covid-19 pandemic. Meanwhile, Muhammad Irwan Padli (2014) explains that service development and implementation, evaluation, and control system; technology automation, and cyber technology are urgent to face many issues in education. With the Fourth Industrial Revolution and $21^{\text {st }}$ Century learning, institutions are expected to continuously make innovations and new ideas and create opportunities, helping people face the Industrial Revolution.

\section{CONCLUSION}

In this research, we analyzed 1) The concept of integrated one-stop licensing services to improve the licensing service quality in Gorontalo, 2) The determinants of the licensing service quality in Gorontalo, and 3) The effectiveness of online-based licensing services at DPM-PTSP 
in the Fourth Industrial Revolution. Our findings are: 1) Service: less optimized online-based licensing services, complicated service delivery, lack of human resources, and inadequate facilities and infrastructures; 2) Online-based program implementation: less optimized onlinebased licensing services as the service program was recently implemented by DPM-PTSP and there were several challenges found i.e. a) limited human resources, b) customers' lack of understanding about the online licensing services, c) limited facilities and infrastructures, especially to the customers with inaccessible Internet network; and 3) Activity programs: which should be improved by a) optimizing education and special training for the staff managing the online licensing services, b) Giving direct socialization to the public, especially those who could not access the Internet, c) Completing facilities and infrastructures through goods provision budgeting, d) Optimizing the service delivery, in terms of the process and output. Furthermore, DPM-PTSP should be able to solve each problem complained by the customers and improve their performances, and e) Implementing systematic online services to improve public services.

Meanwhile, the strategies to overcome challenges found in the online-based licensing services in the Capital Investment and Integrated One-stop Services of Gorontalo are: 1) Improving the human resources, 2) Optimizing the socialization of service procedures, 3) Establishing cooperation with relevant stakeholders, offices, apparatuses, and all public elements who are potential customers of online licensing services, 4) Planning the budget, 5) Providing online licensing administration in each village in the form of manual or hard copies to fulfill the public needs well, and 6) Facing the technical challenges in the Fourth Industrial Revolution by a) Establishing collaborative works and b) Developing technology and using exponential data.

\section{REFERENCES}

Aneta, A., Aneta, Y., \& Dama, H. (2019). Institutional Problems in Regional Public Services. Jurnal Ilmiah Ilmu Administrasi Publik, 8(2), 79-86.

Anggara, S. (2012). Ilmu Administrasi Negara: Kajian Konsep, Teori, dan Fakta Dalam Upaya Menciptakan Good Governance (Vol. 1). CV Pustaka Setia.

Ansell, C., \& Gash, A. (2008). Collaborative governance in theory and practice. Journal of Public Administration Research and Theory. https://doi.org/10.1093/jopart/mum032

Bratamanggala, R. (2017). Implications of tax receivables and retribution for the economic growth of Indonesia.

Creswell, J. W. (2013). Research Design: Qualitative Approach, Quantitative and Mixed. Yogyakarta: Student Library.

Creswell, J. W., \& Creswell, J. D. (2017). Research design: Qualitative, quantitative, and mixed methods approaches. Sage publications.

Creswell, J. W., \& Poth, C. N. (2018). Qualitative inquiry Research Design Choosing Among Five Approaches (Vol. 53, Issue 9). SAGE Publications Ltd. https://doi.org/10.1017/CBO9781107415324.004 
156 |Jurnal Ilmiah Ilmu Administrasi Publik: Jurnal Pemikiran dan Penelitian Administrasi Publik Volume 1o Number 1, January - June 2020. Page 143-158

Daraba, D., Subianto, A. B., \& Salam, R. (2018). Upaya Peningkatan Kualitas Tenaga Kerja pada Dinas Ketenagakerjaan Di Kota Makassar. Jurnal Ilmiah Ilmu Administrasi Publik: Jurnal Pemikiran Dan Penelitian Administrasi Publik, 8(1), 21-26.

Harmelia, H., \& Endriani, D. (2019). The Effect of Market Revitalization towards Original Local Government Revenue (PAD)(Case Study: Padang Market). 2nd Padang International Conference on Education, Economics, Business and Accounting (PICEEBA2 2018).

Junus, D., \& Napir, S. (2019). Analysis Of Competence Of Apparatus In Public Services At The Investment Office And One-Stop Integrated Licensing Service Gorontalo Regency. Prosiding ICOGISS 2019, 466-472.

Kaleem, M. M., Jabeen, B., \& Twana, M. J. (2013). Organizational justice in performance appraisal system: Impact on employees satisfaction and work performance. International Journal of Management \& Organizational Studies, 2(2), 28-37.

Katavich, K. M. (2013). The importance of employee satisfaction with performance appraisal systems: a thesis presented in partial fulfilment of the requirements for the degree of Master of Arts in Psychology at Massey University, Albany, New Zealand. Massey University.

Lamangida, T., Akib, H., Akbar, M. F., \& Aswar, M. (2017). Actors' Role in Public Asset Management--A Study of Limboto Lake in Gorontalo, Indonesia. International Conference on Administrative Science (ICAS 2017).

Lesmana, R. A. (2016). Mekanisme Pelayanan Surat Izin Usaha Perdagangan (SIUP) Pada Badan Pelayanan Perizinan Terpadu Satu Pintu (BPPTSP) Kota Samarinda. Jurnal Administrasi Negara, 2.

Liu, S., Wang, L., Zhang, T., Liu, C., Liang, H., Zhang, Y., \& Guo, D. (2019). Factors affecting the work competency and stability of family doctors in Shanghai: a tracking study. BMC Family Practice, 20(1), 95.

Miles, M. B., Huberman, A. M., \& Saldana, J. (2014). Qualitative Data Analysis: A Methods Sourcebook (3rd ed.). Sage Publications.

Mirdawati, M., Jamaluddin, J., Niswaty, R., Darwis, M., \& Salam, R. (2018). The effectiveness of IMB Services at the Makassar City Investment Office and One Door Integrated Services at Makassar City. Jurnal Ilmiah Ilmu Administrasi Publik, 8(1), 37-44.

Nasrullah, M., Ilmawati, I., Saleh, S., Niswaty, R., \& Salam, R. (2018). Minat Menjadi Guru Pada Mahasiswa Program Studi Pendidikan Administrasi Perkantoran Fakultas Ilmu Sosial Universitas Negeri Makassar. Jurnal Ad'ministrare, 5(1), 1-6.

Saggaf, H. M. S. (2016). Kebijakan Pendidikan Di Era Otonomi Daerah Dalam Memperkuat Karakter Bangsa. Jurnal Ilmiah Ilmu Administrasi Publik, 5(2), 106-112.

Saggaf, S., Salam, R., Kahar, F., \& Akib, H. (2014). Pelayanan Fungsi Administrasi Perkantoran Modern. Jurnal Ad'ministrare, 1(1), 20-27. 
Salam, R., \& Rosdiana. (2015). Penerapan Fungsi Administrasi Perkantoran Modern berbasis Daya Saing Organisasi dalam menyongsong MEA 2015. SEMINAR NASIONAL "Revolusi Mental Dan Kemandirian Bangsa Melalui Pendidikan Ilmu-Ilmu Sosial Dalam Menghadapi MEA 2015” Himpunan Sarjana Pendidikan Ilmu-Ilmu Sosial Indonesia, 1, 186-190.

Saputra, A. D., Pratama, A. B., \& Orbawati, E. B. (2019). Public Service Transformation (A Case Study of Online Single Submission at The Office of Investment and Integrated Services Magelang Municipality). Jurnal Ilmiah Ilmu Administrasi Publik, 9(1), 76-86.

Smith, A., \& Akib, H. (2015). The implementation effectiveness of trash management in Ambon, Maluku: The influence of socialization, coordination and control to the effectiveness of trash management. International Journal of Public Administration, $38(10), 683-688$.

Sugiyono. (2016). Metodologi Penelitian Kuantitatif, Kualitatif, dan R\&D. In CV Alfabeta. https://doi.org/https://doi.org/10.3929/ethz-b-000238666

Suharsimi, A. (2013). Prosedur Penelitian: Suatu Pendekatan Praktik (Edisi Revisi). Jakarta: Rineka Cipta. https://doi.org/10.1017/CBO9781107415324.004

Sumada, I. M. (2018). Quality of Permit Issuance Services to Realize A Good Governance (Case Study at the Integrated Licensing Services Agency of Badung Regency). SINTESA (Jurnal Ilmu Sosial Dan Ilmu Politik), 9(2), 64-72.

Van Meter, D. S., \& Van Horn, C. E. (1975). The Policy Implementation Process: A Conceptual Framework. Administration \& Society, 6(4), 445-488. https://doi.org/10.1177/009539977500600404

Warouw, C. V., Tommy, P., \& Arie, F. V. (2018). Pengaruh Struktur Kepemilikan dan Ukuran Dewan Direksi terhadap Kinerja Perbankan pada Bank Pembangunan Daerah Indonesia tahun 2011-2015. Jurnal EMBA: Jurnal Riset Ekonomi, Manajemen, Bisnis Dan Akuntansi, 6(1).

Wenda, W. L., \& Akib, H. (2015). Pembangunan Ekonomi dalam Era Otonomi Daerah di Kabupaten Pegunungan Bintang, Indonesia. Jurnal Ilmiah Ilmu Administrasi Publik, 5(1), 43-51. 
158 |Jurnal Ilmiah Ilmu Administrasi Publik: Jurnal Pemikiran dan Penelitian Administrasi Publik Volume 1o Number 1, January - June 2020. Page 143-158 